\title{
Effects of the introduction of an omnivorous fish on the biodiversity and functioning of an upland Amazonian lake
}

\author{
Regina L. G. NOBRE ${ }^{1 *} \oplus$, Adriano CALIMAN ${ }^{1}$, Rafael D. GUARIENTO², Reinaldo L. BOZELLI' \\ Luciana S. CARNEIRO ${ }^{1}$ \\ Universidade Federal do Rio Grande do Norte - UFRN, Centro de Biociências, Departamento de Ecologia, Natal, RN, Brasil \\ 2 Universidade Federal do Mato Grosso do Sul - UFMS, Centro de Ciências Biológicas e da Saúde, Campo Grande, MS, Brasil \\ 3 Universidade Federal do Rio de Janeiro - UFRJ, Centro de Ciências da Saúde, Instituto de Biologia, Departamento de Ecologia, Rio de Janeiro, RJ, Brasil \\ * Corresponding author: reginanobre.eco@gmail.com; (1) https://orcid.org/0000-0001-9866-3467
}

\begin{abstract}
The introduction of nonnative species is one of the main threats to freshwater ecosystems. Although omnivory and intraguild predation are common in those systems, little is known about the effects of introduced omnivorous fish on pelagic and littoral communities. This study tested predictions of food-web theory regarding the effects of omnivorous fish introduction on previously fishless lakes in the Amazonian uplands of Serra dos Carajás, Pará, Brazil. The trophic structure of two similar lakes, one with and the other without the introduced omnivorous fish Astyanax bimaculatus, was compared using a data series of biotic variables collected from both lakes twice a year from 2010 to 2013. Zooplankton was more abundant in the lake with fish, and the zooplankton composition differed between lakes. Phytoplankton richness and chlorophyll- $a$ were higher in the lake with the introduced fish than in the fishless lake regardless of phosphorus limitation. For the benthic macroinvertebrate communities, species richness and biomass were higher in the fishless lake. Our results also indicate that $A$. bimaculatus has the potential to link pelagic and littoral habitats through nutrient cycling. The differences observed between the studied lakes are consistent with predictions from food-web theory regarding the effects of multichain omnivorous fish on trophic dynamics. Despite limitations regarding replication at the ecosystem level, it is possible to infer from our findings that the introduction of an omnivorous fish might have changed lake overall functioning.
\end{abstract}

KEYWORDS: trophic cascade, species translocation, community structure, biological invasions, omnivory

\section{Efeitos da introdução de um peixe onívoro sobre a biodiversidade e funcionamento de um lago de altitude amazônico}

\section{RESUMO}

A introdução de espécies não nativas é uma ameaça aos ecossistemas de água doce. Embora a onivoria e a predação intraguilda sejam comuns nesses sistemas, os efeitos da introdução de peixes onívoros nas comunidades pelágicas e litorâneas é pouco conhecido. Nós testamos as previsóes da teoria da teia trófica considerando os efeitos da introdução de um peixe onívoro em um lago previamente desprovido de peixes localizado na Serra dos Carajás, Pará, Brasil. A estrutura trófica em dois lagos similares, um com a presença do peixe onívoro introduzido Astyanax bimaculatus, e outro sem peixes, foi comparada através de uma série de dados bióticos amostrados entre 2010 e 2013. A comunidade zooplanctônica foi mais abundante no lago com peixe e sua composição diferiu entre os dois lagos. Apesar da limitação por fósforo no lago com peixe, a riqueza do fitoplâncton e a concentração de clorofila- $a$ foram maiores nesse lago. A comunidade de macroinvertebrados bentônicos apresentou maior riqueza e biomassa no lago sem peixe. Nossos resultados também indicam que $A$. bimaculatus tem o potencial de acoplar as comunidades litorâneas e pelágicas através da reciclagem de nutrientes. Apesar das limitaçôes relacionadas à ausência de replicação no nível de ecossistemas, nós argumentamos que o nosso estudo mostra que a introdução do peixe onívoro pode ter causado mudanças no funcionamento do lago.

PALAVRAS-CHAVE: cascata trófica, translocação de espécies, estrutura de comunidades, invasôes biológicas, onivoria

CITE AS: Nobre, R.L.G.; Caliman, A.; Guariento, R.D.; Bozelli, R.; Carneiro, L.S. 2019. Effects of the introduction of an omnivorous fish on the biodiversity and functioning of an upland Amazonian lake. Acta Amazonica 49: 221-231. 


\section{INTRODUCTION}

Although freshwater systems only represent approximately $0.01 \%$ of the total Earth surface, they hold a proportionally large fraction $(9.5 \%)$ of the world's total biodiversity (Balian $e t$ al. 2008). In recent years, the maintenance of this biodiversity has been threatened in several ways (Heino et al. 2009; Strayer and Dudgeon 2010), with species introduction being broadly recognized as one of the main threats to freshwater biodiversity (Sala et al. 2000; Rahel 2000; Paolucci et al. 2013). In particular, it has been recently argued that the impact of introduced species is underestimated because most studies do not consider translocated species (i.e., species introduced within their native biogeographical zone in localities where they did not historically occur). These translocated species can impact local diversity and community composition as strongly as exotic species (Matsuzaki et al. 2013; James et al. 2015; Nackley et al. 2017).

When a novel predator is introduced into a system, it can establish interspecific relationships with the native biota and change the structure of interactions occurring in this system. Therefore, introduced species can affect ecological patterns at distinct ecological levels (Rahel 2000; Ricciardi and MacIsaac 2011; Paolucci et al. 2013), from the individual to ecosystem. Thus, introduced species can affect organism behavior and morphology, population density (McIntosh and Townsend 1994; Strayer 2010), species richness, species composition, trophic structure (Ellis et al. 2011; Matsuzaki et al. 2013), nutrient dynamics, and primary production (Vanni 2002; McIntyre et al. 2008; Walsh et al. 2016). These interferences can occur due to mechanisms such as habitat modification (Crooks 2002), competition, predation, and endemic species extinction (Zaret and Paine 1973; Crivelli 1999; McDowall 2006) as well as through indirect interactions, such as those caused by trophic cascades (Rahel 2000; Ricciardi and MacIsaac 2011; Walsh et al. 2016).

Studies of energy flow and trophic interactions in aquatic ecosystems have classically focused on pelagic food chains with direct, linear and simplified trophic architectures (Vander Zanden and Vadeboncoeur 2002). However, real food webs are much more complex and include interactions such as omnivory and intraguild predation, which can buffer or even reverse relationships among predators, prey, and producers (Hart 2002; Vadeboncoeur et al. 2005; Pujoni et al. 2016). The paradigm of simplified, isolated and linear aquatic food webs is being replaced by an intricate whole-lake ecosystem view that involves mechanisms such as trophic coupling through cross-habitat foraging and energy flow beyond habitat boundaries (e.g., when a fish feeds in the benthic compartment of the lake and excretes in the pelagic habitat, thus translocating resources from one compartment to another) (Vanni 2002, Williamson et al. 2018). This ecosystemic view reinforces the importance of energy sources in littoral, benthic and terrestrial habitats and indirect effects that are likely to be important in food webs (Nakano and Murakami 2001; Leroux and Loreau 2008; Vander Zanden et al. 2011).

Omnivorous fish are widespread in tropical freshwater environments (Winemiller 1990; Jeppesen et al. 2010) and can affect trophic interactions in aquatic systems in a myriad of ways triggered by top-down (predation) and bottom-up (nutrient recycling) mechanisms (Vanni 2002; Salazar-Torres et al. 2015). Those mechanisms can be summarized as two basic routes: the direct effects of fish predation, excretion and egestion of nutrients and the indirect pathway through changes in zooplankton grazing rates and zooplankton nutrient cycling influenced by predator effects on zooplankton community structure and composition (Vanni and Findlay 1990). An additional level of complexity occurs because many fish are multichain omnivores, meaning that they exploit food chains based on both littoral and pelagic primary sources (Vadeboncoeur et al. 2005). Thus, effects caused in one habitat (pelagic or littoral) may generate a chain reaction and affect other habitats (Chandra et al. 2005). Omnivorous fish are specially common in tropical environments, where their effects may be of particular interest.

In this study, we compared empirical data with predictions from food-web theory. Specifically, we examined the potential effects of fish introduction by comparing two upland Amazonian lakes in close proximity (Amendoim and Violão lakes) in the eastern Brazilian Amazon. Astyanax bimaculatus is a fish native to the Amazonas River basin. It was artificially introduced to Violão Lake, an originally fishless lake located in the region of Serra dos Carajás. The occurrence of $A$. bimaculatus has been recorded in Violão Lake since 2001, a few years after mining activities started near this region. This voracious species is a visual predator that can feed in different compartments of the lake (pelagic and littoral benthic compartments). Studies on the diet of Astyanax species have shown that members of this genus mostly dwell in the littoral zone and that they predominantly consume insects. However, they also present opportunistic omnivorous habits, as they feed on zooplankton, algae, and macrophytes when insects are scarce (Esteves and Galetti 1995; Casatti et al. 2003). This specific event of fish introduction represents a unique opportunity to address the effects of fish introduction/translocation in pristine systems.

Taking into account that the food webs of these lakes are mainly composed of phytoplankton and zooplankton as part of the basal trophic levels and benthic macroinvertebrates as primary consumers, and considering that $A$. bimaculatus preferably, but not only, forages in the littoral habitat, we expected that the presence of $A$. bimaculatus would have weak negative effects on the structure and composition of the pelagic communities (phytoplankton and zooplankton) of Violão Lake. We expected these weak effects to occur because intraguild predation and omnivory can lead to indirect effects that can buffer predation effects. We also hypothesized that the presence of $A$. bimaculatus would have strong negative effects on littoral communities, 
leading to a lower abundance of Chaoboridae and benthic macroinvertebrates due to direct predation, and would cause changes in macroinvertebrate composition and species richness.

\section{MATERIAL AND METHODS}

\section{Study area and fish species}

The study was conducted in two Amazonian mesotrophic upland lakes (mean altitude $710 \mathrm{~m}$ ), Violáo and Amendoim, located in Canaã dos Carajás municipality in the southeastern portion of Carajás National Forest - FLONA Carajás (06 33'00"S, $49^{\circ} 53^{\prime} 00^{\prime \prime}-50^{\circ} 45^{\prime} 00^{\prime \prime} \mathrm{W}$; Figure 1), in the northern Brazilian state of Pará. The climate in this region is characterized by a long rainy season, with an average annual rainfall of approximately $2126 \mathrm{~mm}$ and an average annual temperature of $24.8^{\circ} \mathrm{C}$ (Silva et al. 1986).

FLONA Carajás has several unique aquatic systems, including lakes formed by rainfall accumulation on lateritic soils. The great majority of lakes in this area are temporary, shallow, fishless lakes (Lopes et al. 2011). The Amendoim and Violão lakes were chosen among the perennial lakes found in the area because of their structural simplicity, their geographical proximity (approximately $1.8 \mathrm{~km}$ apart), and their similar geomorphological and limnological characteristics (Table 1). In addition, these two lakes are not hydrologically connected because they are separated by an intermediate basin that prevents any superficial connection of water between them (Silva et al. 2018).

Astyanax bimaculatus (Characidae) has a total length of 4.5 to $10.9 \mathrm{~cm}$ (Abdon Silva et al. 2015) and is usually overlooked in ecological assessment studies conducted in Neotropical regions (Paiva et al. 2006). This species is native to the Amazon basin and was introduced to Violáo Lake, an originally fishless lake, in the 1990s. Due to its feeding plasticity and the absence of natural predators and competitors, $A$. bimaculatus has become extremely abundant in this lake. However, it is completely absent from Amendoim Lake, which remains fishless. Therefore, Amendoim Lake can be considered as a reference lake to evaluate the effects of the introduction of $A$. bimaculatus on the ecological patterns of Violão Lake and the possible associated mechanisms (Carpenter et al. 1995, Carpenter et al. 2011). From here on, Amendoim and Violão lakes will be referred to as the fishless lake and the fish lake, respectively.

\section{Data sampling for community composition}

The lakes were sampled twice a year from 2010 to 2013. Samples were taken at the end of the rainy and dry seasons (April and November, respectively). To compare the structure (richness and abundance) and composition of the biological communities in the two lakes, quantitative data on phytoplankton, zooplankton, and littoral benthic macroinvertebrates were collected.

In each lake, 1-L water samples were collected from three different points across the pelagic region of the lakes, and these samples were then integrated and analyzed for phytoplankton abundance (individuals $\mathrm{L}^{-1}$ ) and chlorophyll- $a$, which is a proxy for phytoplankton biomass (Huot et al. 2007, Boyer et al. 2009). Additionally, $100 \mathrm{~mL}$ of water were collected from the central part of each lake and fixed with Lugol's iodine solution for subsequent identification in the laboratory. Phytoplankton species were identified and counted using an inverted microscope. The units (cells, colonies, and filaments) were enumerated in random fields until at least 100 specimens of the most frequent species were counted.

Zooplankton and Chaoboridae samples were collected in three different areas of the pelagic zone of the lake by taking vertical hauls with a $50 \mu \mathrm{m}$ mesh plankton net. The samples were immediately fixed with formaldehyde at a

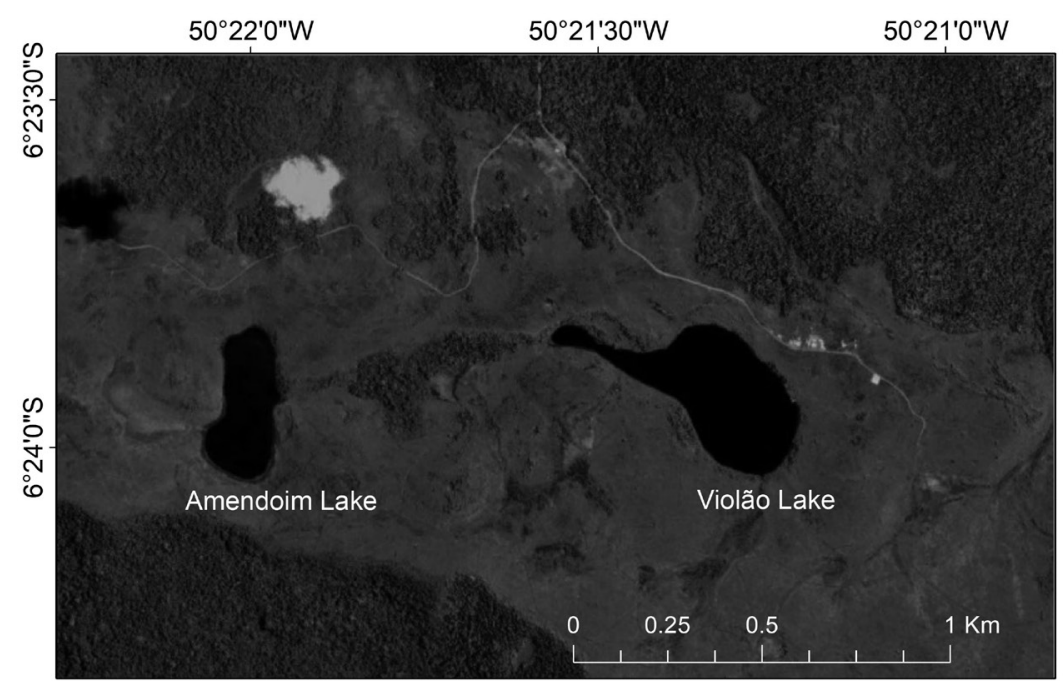<smiles>N=C1NC(F)S1</smiles>

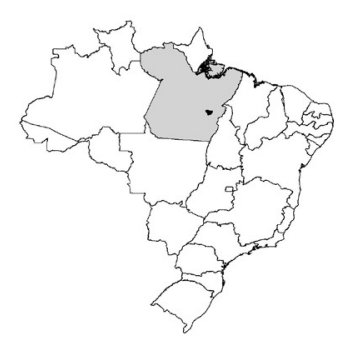

Figure 1. Location of the two studied lakes [Amendoim Lake (fishless) and Violão Lake (with introduced Astyanax bimaculatus)], in the southern portion of Carajás National Forest, Pará, Brazil. 
Table 1. Abiotic characterization (mean \pm SD and number of samplings) of Violão and Amendoim lakes. Samples were taken twice a year from 2010 to 2013.

\begin{tabular}{lcc}
\hline Abiotic Variables & Violão Lake & Amendoim Lake \\
\hline Area & $29.6 \mathrm{ha}$ & $13.96 \mathrm{ha}$ \\
Elevation & $735 \mathrm{~m}$ & $713 \mathrm{~m}$ \\
Depth (maximum) & $11.5 \mathrm{~m}$ & $7.8 \mathrm{~m}$ \\
\hline Temperature & $27.02^{\circ} \mathrm{C} \pm 0.28(6)$ & $26.42^{\circ} \mathrm{C} \pm 0.52(6)$ \\
$\mathrm{pH}$ & $5.51 \pm 0.31(6)$ & $5.23 \pm 0.34(6)$ \\
\hline Turbidity (NTU) & $3.30 \pm 0.34(6)$ & $2.17 \pm 1.10(6)$ \\
\hline
\end{tabular}

final concentration of $4 \%$. The zooplankton in triplicate aliquots of the samples were counted in a Sedgewick-Rafter counting chamber under a microscope for rotifers and in an open chamber under a stereomicroscope for cladocerans and copepods. At least 100 individuals per aliquot were counted. To obtain an approximate measurement of zooplankton biomass, average values of zooplankton species dry weight obtained from the literature (e.g., Hall 1970; Bottrel et al. 1976) were multiplied by the corresponding abundance. Chaoboridae samples were also counted in an open chamber under a stereomicroscope.

Littoral macroinvertebrates were collected from five different areas of the littoral zone of each lake using a sieve with 1-mm mesh and 50-cm diameter. One sample was taken from each of the five areas and sieved. The samples were integrated, and then macroinvertebrates were fixed with $70 \%$ alcohol solution. Individuals were counted and identified to the lowest possible taxonomic unit. For more detailed information on the methods used for the sampling and identification of the biotic communities, see Lopes et al. (2011). The species list and abundance data for the studied communities are available in the Supplementary Material (Tables S1 to S4).

\section{Data analysis for community composition}

To assess differences in the species richness of the zooplankton, phytoplankton and littoral macroinvertebrates between the lakes, rarefaction curves were constructed using EstimateS (version 9, R. K. Colwell, http://purl.oclc.org/estimates). Graphics were produced using GraphPad Prism 5.0. To compare the total abundances of macroinvertebrates, zooplankton and phytoplankton between the lakes, standardized mean differences [SMD - Cohen's d (Lakens, 2013) with $\pm 95 \%$ confidence intervals (CI)] were calculated for each sampling date $(n=6)$ between the fish and fishless lakes. Confidence intervals were calculated on the basis of a bootstrap technique with 4999 iterations. The abundance of phytoplankton was analyzed as cells $\mathrm{L}^{-1}$ and as chlorophyll-a concentration ( $\mu \mathrm{g} \mathrm{L}^{-1}$ ). Macroinvertebrate and Chaoboridae abundances were measured as individuals $\mathrm{L}^{-1}$. For zooplankton, biomass $\left(\mu \mathrm{g} \mathrm{L}{ }^{-1}\right)$ was used as the metric to compare abundances. Differences between lakes were considered statistically significant if the SMD $\pm 95 \%$ CIs did not overlap zero. These data were analyzed using $\mathrm{R}$ version 3.1.2 (R Development Core Team 2014).

To identify differences between the lakes in terms of the community composition of the phytoplankton, zooplankton and macroinvertebrates, PERMANOVAs were performed using the adonis function in the vegan package (Oksanen et al. 2015) in R version 3.1.2 (R Development Core Team 2014). Differences in composition were analyzed considering both presence/absence (Jaccard similarity matrix) and abundance (Bray-Curtis dissimilarity matrix). The abundance data used to calculate the Bray-Curtis distances were previously log transformed to minimize the influence of dominant species in the analysis. If a sample contained no species, it was excluded from the PERMANOVA. Nonmetric multidimensional scaling (NMDS) with a Jaccard similarity matrix was performed in $\mathrm{R}$ using the standard function metaMDS in the vegan package (Oksanen $e t$ al. 2015) to obtain a graphic representation of the phytoplankton and zooplankton community composition. For littoral macroinvertebrates, instead of NDMS, MDS was performed to represent the community structure because littoral macroinvertebrates were very scarce and distinct among the sampling sites, leading to many pairwise dissimilarities being fully separated (i.e., a dissimilarity measure equal to 1). This situation resulted in multiple converting solutions with zero stress when using NMDS. Therefore, a metric solution is preferred (Oksanen et al. 2015). For all the above analyses, singletons (i.e., species that occurred in only one sample in the dataset with only one individual) were excluded.

\section{Seston C:N:P and fish excretion N:P ratio}

To investigate whether $A$. bimaculatus is a potentially important source of nutrients to phytoplankton, seston C:N:P ratios (molar units) and fish nutrient excretion N:P ratios were quantified. To estimate the C:N:P stoichiometric ratios of the phytoplankton, water from a pelagic portion of Violáo Lake was sampled at various depths in the photic zone using a Van Dorn bottle, and these samples were integrated into a 20-L container. Samples were taken during the dry and rainy seasons of 2012. Then, samples of $500 \mathrm{ml}$ of water from the container were filtered using $0.65 \mu \mathrm{m}$ glass fiber filters (GF/F, Whatman) that were previously incinerated. Then, the filters were dried at $60{ }^{\circ} \mathrm{C}$ for a minimum of 48 hours. Sixteen filters (eight for each season) were analyzed for carbon (C) and nitrogen $(\mathrm{N})$ with a Perkin-Elmer Series $2400 \mathrm{CHN}$ analyzer. To quantify the seston phosphorus $(\mathrm{P})$ content, five filters for each season were individually digested with 3\% potassium persulfate to convert particulate $\mathrm{P}$ to phosphate $\left(\mathrm{PO}_{4}^{-3}\right)$, and the $\mathrm{P}$ concentration was estimated with the acid molybdic method according to Suzumura (2008).

Nutrient excretion rates of $A$. bimaculatus were quantified during the rainy and dry seasons of 2012 in the fish lake. Excretion rates were quantified using methods described in Vanni et al. (2002). Fish were collected using fishing nets and 
vertical hauls. Immediately after capture, the fish were weighed alive and placed into plastic bags (1-21 individuals per bag depending on body mass) containing $1 \mathrm{~L}$ of fish lake water previously filtered through glass fiber filters (GF/F, Whatman) to remove particles that might absorb nutrients. When multiple animals were incubated together, care was taken to assure that all individuals were of similar size. After one hour, the content of the bags was filtered to remove feces and other particles. The filtered samples were analyzed manually for ammonia-N using the phenol-hypochlorite method (Solorzano 1969) and for total dissolved P (TDP) using the acid-molybdic method after persulfate digestion (Suzumura 2008). N and P excretion rates were calculated as the change in ammonia-N or TDP per unit time divided by the wet mass of the animals. In total, we measured excretion rates for 25 replicates (bags) in each season. Due to logistic limitations in the field, seston C:N:P was only measured for the fish lake. Although this may weaken the ability to compare the two lakes, the association between fish excretion and seston nutrient status (a characteristic only possible in the fish lake) could still be investigated. Graphics were produced using GraphPad Prism 5.0.

\section{RESULTS}

Although phytoplankton species richness was higher in the fish lake (Figure 2a), the results of the PERMANOVA and NMDS analysis showed no differences in community composition between the lakes $\left(\mathrm{F}_{\text {Bray-Curtis }}=1.28, \mathrm{df}=11, \mathrm{p}=0.24 ; \mathrm{F}_{\text {Jacard }}\right.$ $=1.17, \mathrm{df}=11, \mathrm{p}=0.32$, Figure 3a). The phytoplankton in both lakes was mainly composed of cyanobacteria of the genus Synechocystis, representing $93 \%$ of the species abundance (cells $\left.\mathrm{L}^{-1}\right)$ in the fishless lake and almost $60 \%$ in the fish lake. No differences were observed for phytoplankton abundance in terms of cells $\mathrm{L}^{-1}$ (Figure $4 \mathrm{~b}$ ); however, the average phytoplankton biomass (measured as chlorophyll- $a$ ) in the fish lake was significantly higher than that in the fishless lake (Figure 4b).

The fish and fishless lakes differed in terms of zooplankton species richness and abundance. While the fishless lake had higher species richness (Figure $2 \mathrm{~b}$ ), the total zooplankton abundance (biomass) was higher in the fish lake (Figure 4b). When the abundances of the zooplankton taxonomic groups were analyzed separately (rotifers, cladocerans, and copepods), no difference between lakes was found for rotifers, but cladocerans and copepods had higher abundances in the fish lake (Figure 4a). In fact, almost no copepods or cladocerans were found in the fishless lake. The zooplankton communities differed between the lakes regardless of the distance matrix used $\left(\mathrm{F}_{\text {Bray-Curtis }}=1.61\right.$, $\mathrm{df}=11, \mathrm{p}=0.04 ; \mathrm{F}_{\text {Jaccard }}=3.99, \mathrm{df}=11, \mathrm{p}=0.005$, Figure $3 \mathrm{~b}$ ). Most of the species sampled in the fishless lake, in terms of relative biomass, were rotifers (72\%), which were less abundant in the fish lake (26\%). Cladocerans represented $43 \%$ of the zooplankton relative biomass in the fish lake, while copepods represented $30 \%$, in contrast to cladocerans representing $28 \%$ of the zooplankton relative biomass in the fishless lake and virtually no copepods occurring within it.

The fishless lake presented a clear pattern of higher species richness (Figure 2c) and abundance (Figure $4 \mathrm{~b}$ ) for littoral macroinvertebrates. The PERMANOVAs, regardless of whether quantitative or qualitative data were used, showed that the macroinvertebrate community composition differed between the two lakes $\left(\mathrm{F}_{\text {Bray-Curtis }}=1.59, \mathrm{df}=8, \mathrm{p}=0.005 ; \mathrm{F}_{\text {Iaccard }}\right.$ $=2.18, \mathrm{df}=8, \mathrm{p}=0.001)$. The MDS results also supported this
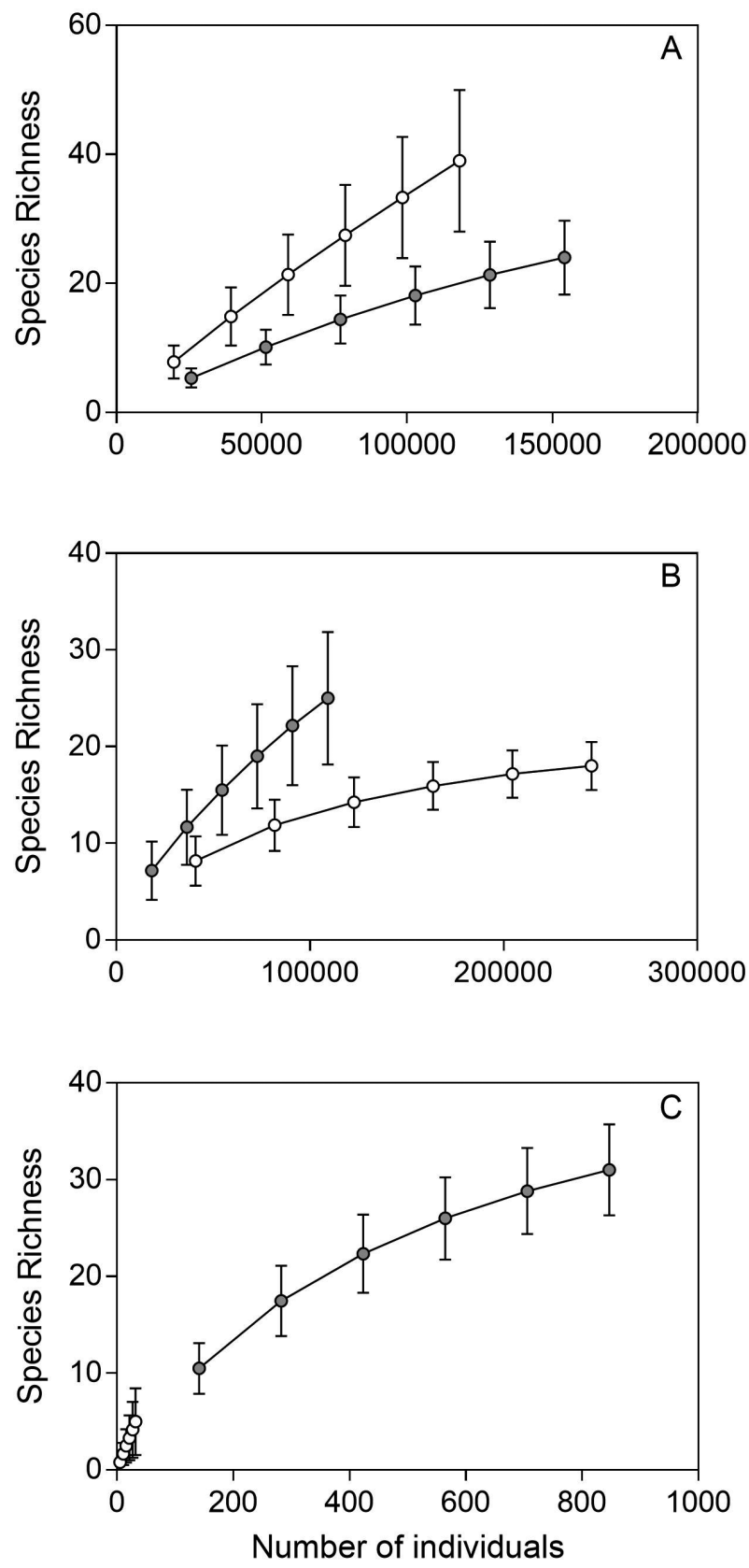

Figure 2. Rarefaction curves for species richness comparisons of (a) phytoplankton, (b) zooplankton and (c) littoral macroinvertebrate communities between the fishless (gray dots) and fish lakes (white dots). Bars depict 95\% confidence intervals. 

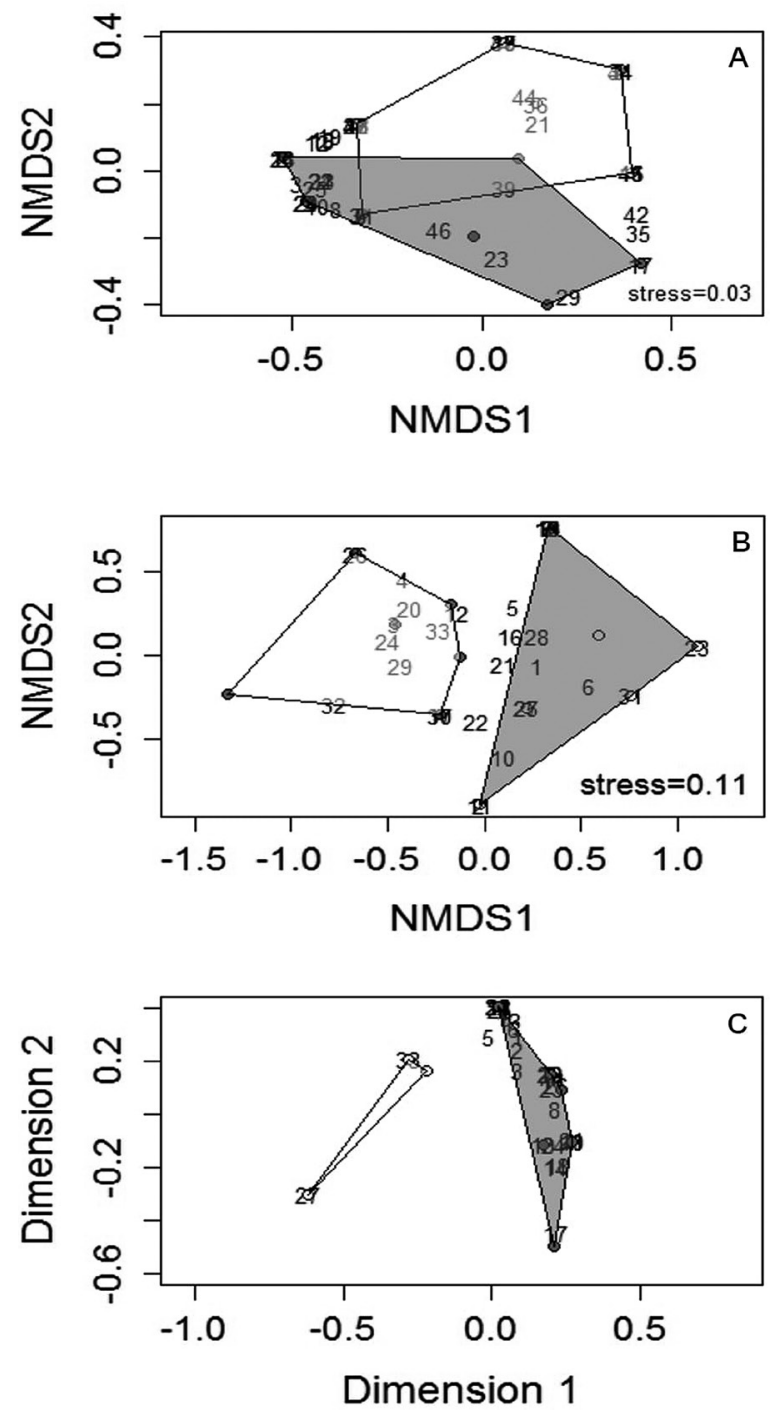

Figure 3. Nonmetric multidimensional scaling (NMDS) plots based on a Jaccard similarity matrix contrasting (a) phytoplankton and (b) zooplankton species composition in the fish (white) and fishless (gray) lakes. Numbers indicate the species scores for the plot. (c) Multidimensional scaling (MDS) plot based on the Jaccard similarity matrix of macroinvertebrate communities. Species identifications are available in the Supplementary Material (Tables S1 to S3).

finding (Figure 3c). Among the littoral macroinvertebrates, dipterans and hemipterans were the most abundant taxonomic groups in the fishless lake, accounting for $26 \%$ and $38 \%$, respectively, of the littoral macroinvertebrate abundance. In the fish lake, Chelicerata was the most abundant group, accounting for $53 \%$ of the total macroinvertebrate abundance. When analyzing the difference in Chaoboridae abundance between the two lakes, we found that this group presented a higher abundance in the fishless lake (Figure 4b).

The seston C:N:P molar ratio in the fish lake was 781:84:1 on average in the rainy season and 1367:134:1 in the dry season (Supplementary Material, Table S5). Phytoplankton
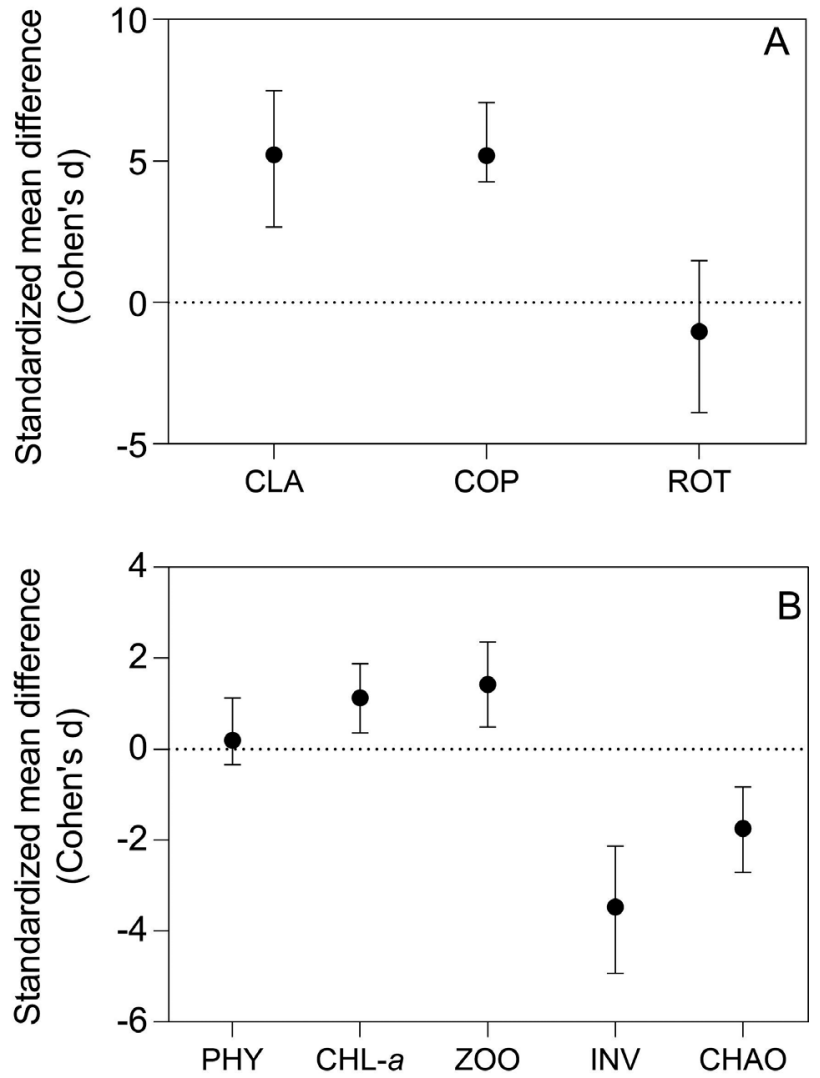

Figure 4. Effect sizes (mean $\pm 95 \% \mathrm{Cl}, \mathrm{n}=6$ ) calculated as the standardized mean difference (SMD) for (A) biomass of zooplankton groups $\left(\mu \mathrm{L} \mathrm{L}^{-1}\right)$ and (B) abundances

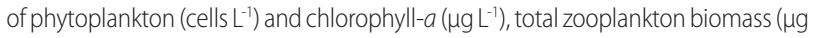
$L^{-1}$ ), littoral invertebrates, and Chaoboridae (individuals $L^{-1}$ ). Individual effect sizes were calculated for each response variable considering the difference for a given value of a response variable in the fish lake and the respective value for the same response variable in the fishless lake. Therefore, positive values indicate a greater effect on the fish lake compared to the fishless lake. Effect sizes are statistically significant when their $95 \% \mathrm{Cl}$ did not overlap zero (the dotted line).

growth in the fish lake can be considered exclusively P-limited when comparing the seston $\mathrm{C}: \mathrm{N}: \mathrm{P}$ ratios with ranges of $\mathrm{C}: \mathrm{N}: \mathrm{P}$ ratios that indicate nutrient limitation (Figure 5). The stoichiometry ( $\mathrm{N}: \mathrm{P}$ ratio) of the excretion-mediated nutrient recycling by $A$. bimaculatus was much lower than the N:P ratio for phytoplankton, with average values of $43: 1$ and 21:1 in the rainy and dry seasons, respectively.

\section{DISCUSSION}

While the lack of ecosystem-level replicates limits inference about causal effects of fish presence on community structure on Carajás lakes, our findings are suggestive of a strong effect that should not be dismissed (Davies and Gray 2015). Moreover, the replication of the comparative study would be hampered by the fact that no other lake in the region has suffered from the introduction of $A$. bimaculatus, and more distant lakes likely differ geographically and physicochemically 

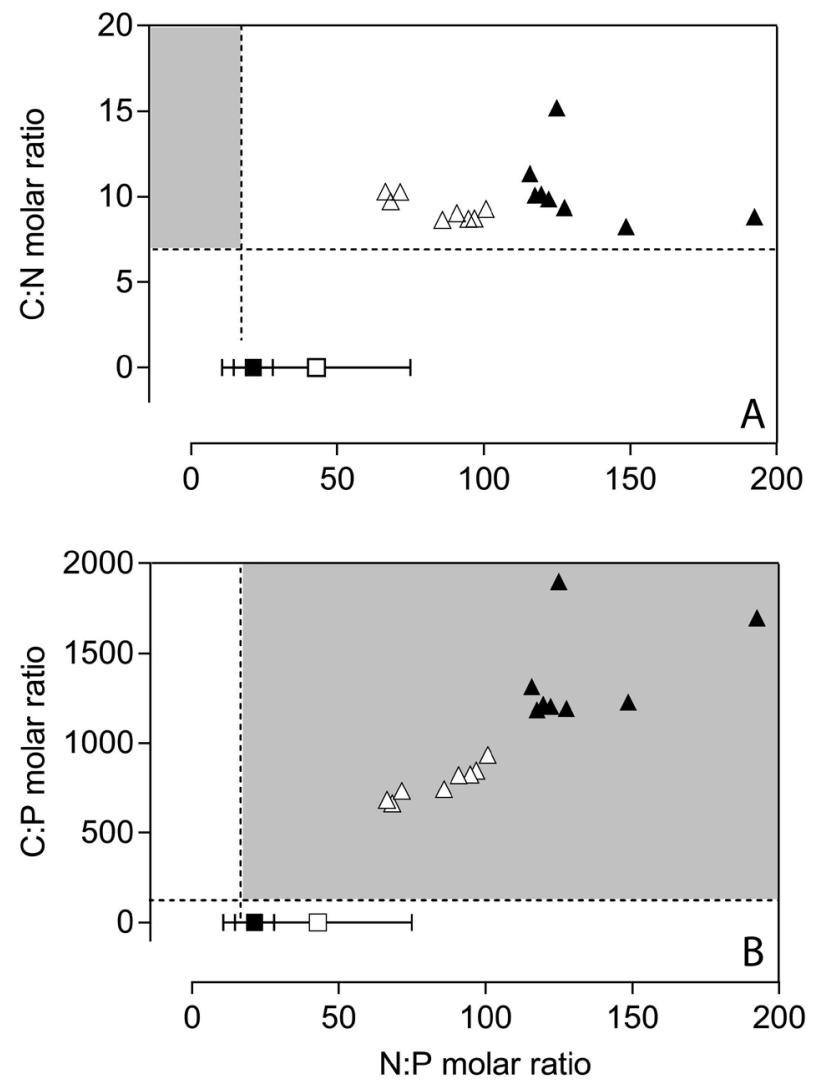

- Seston dry season

$\triangle$ Seston rainy season

Fish N:P excretion ratio rainy season

- Fish N:P excretion ratio dry season

Figure 5. C:N:P molar ratios for seston and N:P molar ratios for Astyanax bimaculatus excretion rates in the fish lake measured in the dry and rainy seasons of 2012. Lines are optimal C:N:P ratios for periphyton growth (119:17:1) that can be applied for phytoplankton and were derived from Hillebrand and Sommer (1999). Gray areas indicate nutrient limitation of phytoplankton growth. The gray area in (a) depicts high C:N values in combination with low N:P values, indicating phytoplankton N limitation. The gray area in (b) depicts high C:P values in combination with high N:P values, indicating phytoplankton P limitation. Error bars are \pm SD.

from our lakes, which may have confounding effects on the potential influence of fish. The remarkable similarity in physical, chemical, physiographical and geographical conditions between the lakes studied allows for the comparison of the fish and fishless lakes and the evaluation of our results in light of food-web theory. This comparison helped to elucidate the potential effects of the introduction of an omnivorous fish in these aquatic ecosystems.

According to the classical view of the effects of omnivorous consumers and considering the feeding habits of $A$. bimaculatus, we expected that the presence of this fish would have only weak effects on the pelagic communities but strong effects on the littoral communities. Indeed, negative effects on macroinvertebrate abundance were observed in the fish lake; in addition, the fish and fishless lakes also differed in terms of the structure and composition of the planktonic communities, although they were less pronounced than the differences found for the littoral communities.

In light of trophic cascade theory (Carpenter et al. 1985), we expected that the presence of a visual predator fish would have a negative effect on zooplankton abundance, but the zooplankton biomass was higher in the lake in which the fish was introduced. Tropical and subtropical lakes are known to have buffering mechanisms that can suppress the occurrence of topdown trophic cascades (Drenner and Hambright 2002; Jeppesen et al. 2005). For instance, tropical lakes mostly contain small zooplankton species (Gillooly and Dodson 2000), while largebodied mesozooplankton species are considered to be key factors in the control of algal biomass (Dawidowicz 1990). Additionally, these tropical lakes contain juvenile fish and invertebrate predators, such as Chaoboridae larvae, which are dominant and reproduce throughout the year, imposing high predation pressure on zooplankton (Van Leeuwen et al. 2007; Pujoni et al. 2016). Therefore, although the pattern we found in regard to zooplankton abundance may contradict the overall expectation of fish-driven differences between lakes, it may be explained by intraguild predation (Polis and Holt 1992, Holt and Polis 1997) and the feeding preferences of $A$. bimaculatus for littoral resources (Esteves and Galetti 1995; Andrian et al. 2001). As this fish species preferentially feeds in the littoral zone, decreasing the abundance of Chaoboridae and macroinvertebrates (some of which are also potential predators of zooplankton), it is possible that the presence of the fish released zooplankton from predation through its preferential predation on macroinvertebrates. The persistence of zooplankton in the fish lake can also be thought of as a case of indirect mutualism, as it relies on the presence of fish to be released from macroinvertebrate predation (Boucher $e t a l$. 1982). In addition, zooplankton may also benefit from nutrient translocation by fish from the littoral to the pelagic zone of the lake.

The absence of cladocerans and copepods in the fishless lake may also be related to the increased importance of macroinvertebrates in structuring pelagic communities when there are low levels of fish predation (Hobaek et al. 2002; Hart 2002; Keppeler 2003). Therefore, the absence of natural predators of Chaoboridae and macroinvertebrates, along with their great abundance in the fishless lake, has the potential to impose strong predation pressure on the zooplankton community. There was no difference in rotifer biomass between the lakes, which is in accordance with trophic-cascade theory, which predicts negligible effects of fish presence for this group (Carpenter et al. 1985). The analysis of the zooplankton rarefaction curves showed that the fishless lake is more species rich. Despite the small number of analyzed samples, when the rarefaction curves were extrapolated by twice the size of the empirical sample, the same pattern was observed (Supplementary Material, Figure S1). Lopes et al. (2011) showed that the zooplankton and phytoplankton communities 
of Serra dos Carajás lakes, including Violão and Amendoim, are not limited by spatial factors, such as dispersal. Therefore, the zooplankton community composition in these lakes can be regulated by a combination of dispersal from a regional pool of species and the effects of predation, because predators can facilitate invasion by members of the regional pool through the suppression of competitors or intermediate predators, which may buffer the loss of species due to predation (Carpenter and Kitchell 1996; Kvam and Kleiven 1995; Leibold et al. 1997; Shurin 2001; Burks et al. 2002).

Along with the possibility of preferential fish predation on macroinvertebrates and Chaoboridae, zooplankton may have evolved mechanisms to escape from fish predation. Such behavior may be related to the life history of $A$. bimaculatus, as this species feeds more in littoral zones than in pelagic zones (Arcifa et al. 1991). This habitat preference of $A$. bimaculatus can stimulate behavioral responses in zooplankton related to predation risk, causing the horizontal migration of this community from littoral to pelagic regions of the lake. In aquatic systems, some planktonic organisms can perceive the presence of fish predators through chemical communication (Lass and Spak 2003; Santangelo et al. 2011). Therefore, zooplankton individuals may display anti-predator responses to reduce predation (Walls et al. 1990; Guariento et al. 2014), decreasing the effects of predators on overall zooplankton abundance (de Meester 1993; Loose et al. 1993). However, it is worth noting that zooplankton samples were taken only from pelagic portions of the lakes, and to explore this potential mechanism, it would also be necessary to sample zooplankton from the littoral region.

Although the phytoplankton species richness was higher in the fish lake, the communities were not significantly different in terms of composition or abundance. A possible limitation of this analysis is that abundance quantification as cells $\mathrm{L}^{-1}$ was used instead of a biovolume measure, and some studies indicate that the effects of predation on phytoplankton community structure and composition are less predictable than the effects on phytoplankton biomass (Vanni and Findlay 1990). However, when chlorophyll- $a$ was considered as the metric for quantitative comparisons of phytoplankton, the fish lake showed significantly higher phytoplankton biomass. The higher chlorophyll- $a$ in the fish lake may suggest that phytoplankton dynamics could be controlled by a nutrient shortage, as commonly observed at lower latitudes (Moss et al. 2004). Analysis of nutrient ratios showed that the phytoplankton in the fish lake was limited by phosphorus, specially in the dry season. Therefore, the higher chlorophyll- $a$ in the fish lake may be derived from the availability of nutrients via fish excretion and the translocation of nutrients. Since $A$. bimaculatus N:P excretion ratios were low, this fish can excrete $\mathrm{P}$ at high rates, and can potentially alleviate phytoplankton $\mathrm{P}$ limitation in the fish lake (McIntyre et al. 2008, Small et al. 2011).

As expected according to the hypothesis addressed in this study, our results show the trophic effects of $A$. bimaculatus introduction on the littoral macroinvertebrate community, which was evidenced by a clear difference in species richness, abundance and composition in relation to a fishless lake. In general, macroinvertebrates and Chaoboridae were far less abundant in the fish lake. Large-bodied invertebrate predators, such as those in the Chaoboridae family, are suppressed by fish predation (Dorn 2008, Iglesias et al. 2011), which further supports the notion that the presence of the fish drove the differences in littoral benthic macroinvertebrate communities between the lakes.

Thus, our results support the preference of $A$. bimaculatus for feeding on littoral resources (Arcifa et al. 1991; Esteves and Galetti 1995). The fish is likely to feed preferentially on macroinvertebrates and Chaoboridae in the littoral zone, resulting in comparatively weaker top-down effects on pelagic communities. The observed positive effect of fish on phytoplankton biomass (chlorophyll-a) also supports this idea. It is also important to note that $A$. bimaculatus may be acting as a source of nutrients for the pelagic communities of the lake via nutrient translocation from the littoral to the pelagic zone (i.e., through macroinvertebrate consumption and subsequent excretion into the pelagic habitat). This pathway has been suggested as one of the most important ways in which animals can contribute to nutrient cycling in freshwater systems (Vanni 2002).

Our results show that it is important to consider the effects of translocated fish in studies of species introduction impacts on local biodiversity in such unique aquatic ecosystems. Moreover, to understand the effects of the introduction of an omnivorous fish on freshwater communities, it is necessary to address the complexity of those systems, taking into account not only pelagic-littoral coupling through top-down and bottom-up mechanisms, but also the whole range of effects that multichain omnivorous fish can have on ecosystems.

Our study lakes are part of the Canga ecosystem, which is characterized by ironstone outcrops vegetated by ferruginous montane savanna and bordered by Amazon rainforest (Silva et al. 2018). The Canga and its peculiar freshwater systems are in a state of extreme vulnerability due to iron ore extraction activities (Lopes et al. 2011). Carajás is one of the areas that still holds large areas of these ecosystems that are not drastically altered. Thus, it is necessary to increase efforts to study factors that play a fundamental role in aquatic community composition and diversity in Canga lakes of Carajás, to assist the implementation of conservation strategies to reduce the loss of their biodiversity.

\section{CONCLUSIONS}

A lake in the eastern Brazilian Amazon, in which the characid Astyanax bimaculatus was introduced in the 1990s, differed ecologically from a nearby lake that remained fishless over the time span of this study, from 2010 to 2013. The trophic effects of $A$. bimaculatus seemed to be more prominent in the littoral habitat. Specially regarding the pelagic communities, the differences between the lakes differed from those typically found in temperate lakes, where classic trophic cascade effects usually arise (Schindler and Scheuerell 2002). The greater 
biomass of zooplankton and content of chlorophyll- $a$ in the fish lake may be related to fish foraging behavior. Accordingly, $A$. bimaculatus has the potential to couple lake littoral and pelagic habitats through nutrient translocation via macroinvertebrate consumption and excretion, thereby increasing primary production and potentially affecting zooplankton.

\section{ACKNOWLEDGMENTS}

We acknowledge Dr. Adriana Monteiro, Dr. Alexandre Fadigas, Dr. Ali Ger (UFRN - Universidade Federal do Rio Grande do Norte) and Dr. Michael Vanni (Miami University, Oxford, Ohio), for comments and critiques that led to major contributions to the manuscript. R.L.G. Nobre is thankful to Coordenação de Aperfeiçoamento de Pessoal de Nível Superior (CAPES) for a postgraduate scholarship. A. Caliman and R. L. Bozelli are specially grateful to Conselho Nacional de Desenvolvimento Científico e Tecnológico (CNPq) for continuous funding through research productivity grants. This research was financially supported by Companhia Vale and Instituto Chico Mendes de Conservaçáo da Biodiversidade (ICMBio). We are also thankful to Dra. Erica Caramaschi who provided informations regarding the fish population in the study area.

\section{REFERENCES}

Abdon Silva, L.M.; Brito Oliveira, M.S.; Florentino, A.C.; TavaresDias, M. 2015. Length-weight relationship of 11 fish species from a tributary of the Amazon River system in northern Brazil. Journal of Applied Ichthyology, 31: 816-817.

Andrian, I.D.F.; Silva, H.B.R.; Peretti, D. 2001. Dieta de Astyanax bimaculatus (Linnaeus, 1758) (Characiformes, Characidae) da área de influência do reservatório de Corumbá, estado de Goiás, Brasil. Acta Scientiarum, 23: 435-440.

Arcifa, M.S.; Northcote, T.G.; Froehlich, O. 1991. Interactive ecology of two cohabiting characin fishes (Astyanax fasciatus and Astyanax bimaculatus) in an eutrophic Brazilian reservoir. Journal of Tropical Ecology, 7: 257.

Balian, E.V.; Segers, H.; Lévèque, C.; Martens, K. 2008. The freshwater animal diversity assessment: an overview of the results. Hydrobiologia, 595: 627-637.

Boucher, D.H.; James, S.; Keeler, K.H. 1982. The ecology of mutualism. Annual Review of Ecological Systems, 13: 315-47.

Boyer, J.N.; Kelble, C.R.; Ortner, P.B.; Rudnick, D.T.; Bay, F. 2009. Phytoplankton bloom status : Chlorophyll a biomass as an indicator of water quality condition in the southern estuaries. Ecological Indicators, 95: 556-567.

Burks, R.L.; Lodge, D.M.; Jeppesen, E.; Lauridsen, T.L. 2002. Diel horizontal migration of zooplankton: costs and benefits of inhabiting the littoral. Freshwater Biology, 2002: 343-365.

Carpenter, S.R.; Kitchell, J.F.; Hodgson, J.R. 1985. Cascading trophic interactions and lake productivity. BioScience 35: 634-39.

Carpenter, S.R.; Chisholm, S.W.; Krebs, C.J.; Schindler, D.W.; Wright, R.F. 1995. Ecosystem Experiments. Science, 269: 324-327.
Carpenter, S.R.; Cole, J.; Pace, M.L.; Batt, R.; Brock, W.A.; Cline, T. 2011. Early warnings of regime shifts. Science, 332: 1076-1079.

Carpenter, S.R.; Kitchell, J.F. 1996. The trophic cascade in lakes. Cambridge University Press, Cambridge, UK, 400p.

Casatti, L.; Mendes, H.F.; Ferreira, K.M. 2003. Aquatic macrophytes as feeding site for small fishes in the Rosana reservoir, Paranapanema river, southeastern Brazil. Brazilian Journal of Biology, 63: 213-22.

Chandra, S.; Vander Zanden, M.J.; Heyvaert, A.C.; Richards, B.C.; Allen, B.C.; Goldman, C.R. 2005. The effects of cultural eutrophication on the coupling between pelagic primary producers and benthic consumers. Limnology and Oceanography, 50: 13681376

Colwell, R.K. 2013. EstimateS: Statistical estimation of species richness and shared species from samples Version 9 User's Guide and application. (http://purloclcorg/estimates). Accessed on 01 Mar 2015.

Crivelli, A.J. 1995. Are fish introductions a threat to endemic freshwater fishes in the northern Mediterranean region? Biological Conservation 2: 311-319.

Crooks, J.A. 2002. Characterizing ecosystem-level consequences of biological invasions: the role of ecosystem engineers. Oikos, 97: 153-166.

Davies, G.M.; Gray, A. 2015. Don't let spurious accusations of pseudoreplication limit our ability to learn from natural experiments (and other messy kinds of ecological monitoring). Ecology and Evolution, 5: 5295-5304.

Dawidowicz, P. 1990. Effectiveness of phytoplankton control by largebodied and small-bodied zooplankton. Hydrobiologia, 200/201: 43-47.

de Meester, L.; Weider, L.J.; Tollrian, R. 1995. Alternative anti-predator defenses and genetic polymorphism in a pelagic predator-prey system. Nature, 378: 483-485

Dorn, N.J. 2008. Colonization and reproduction of large macroinvertebrates are enhanced by drought-related fish reductions. Hydrobiologia, 605: 209-218.

Drenner, R.; Hambright, K. 2002. Piscivores, trophic cascades, and lake management. The Scientific World Journal, 2: 284-307.

Ellis, B.K.; Stanforda, J.A.; Goodmanc, D.; Staffordb, C.P.; Gustafsonc, D.L.; Beauchampd, D.A. et al. 2011. Long-term effects of a trophic cascade in a large lake ecosystem. Proceedings of the National Academy of Sciences of the United States of America, 108: 1070-1075.

Esteves, K.E.; Galleti Jr., P.M. 1995. Food partitioning among some characids of a small Brazilian floodplain lake from the Parana River basin. Environmental Biology of Fishes, 42: 375-389.

Heino, J; Virkkala, R.; Toivonen, H. 2009. Climate change and freshwater biodiversity: detected patterns, future trends and adaptations in northern regions. Biological Reviews of the Cambridge Philosophical Society, 84: 39-54.

Guariento, R.D.; Luttbeg, B.; Mehner, T.; Esteves, F.A. 2014. The effect of predation pressure and predator adaptative foraging on the relative importance of consumptive and non-consumptive predator net effects in a freshwater model system. Oikos, 123: 705-713.

Gillooly, J.F.; Dodson, S.I. 2000. Latitudinal patterns in the size distribution and seasonal dynamics of new world, freshwater Cladocerans. Limnology and Oceanography, 45: 22-30. 
Hall, D.J.; Cooper, E.; Werner, E.E. 1970. An experimental approach to the production dynamics and structure of freshwater animal communities. Limnology and Oceanography, 15: 839-928.

Hart, D.R. 2002. Intraguild predation, invertebrate predators, and trophic cascades in lake food webs. Journal of Theoretical Biology, 218: 111-128.

Hillebrand, H.; Sommer, U. 1999. The nutrient stoichiometry of benthic microalgal growth: Redfield proportions are optimal. Limnology and Oceanography, 44: 440-446.

Hobæk, A.; Andersen, M.M. 2002. Factors influencing species richness in lacustrine zooplankton. Acta Oecologica, 23: 155-163.

Holt, R.D.; Polis, G.A. 1997. A theoretical framework for intraguild predation. The American Naturalist, 149: 745-764.

Iglesias, C.; Mazzeo, N.; Meerhoff, M.; Lacerot, G.; Clemente, J.M.; Scasso, F. et al. 2011. High predation is of key importance for dominance of small-bodied zooplankton in warm shallow lakes: evidence from lakes, fish exclosures and surface sediments. Hydrobiologia, 667: 133-147.

James, J.; Slater, F.M.; Vaughan, I.P.; Young, K.A.; Cable, J. 2015. Comparing the ecological impacts of native and invasive crayfish: could native species translocation do more harm than good? Oecologia, 178: 309-316.

Jeppesen, E.; Meerhoff, M.; Holmgren, K.; González-Bergonzoni, I.; Teixeira-de Mello, F.; Declerck, S.A.J. et al. 2010. Impacts of climate warming on lake fish community structure and potential effects on ecosystem function. Hydrobiologia 646: 73-90.

Jeppesen, E.; Søndergaard, M.; Mazzeo, N.; Meerhoff, M.; Branco, C.; Huszar, V. et al. 2005. Lake restoration and biomanipulation in temperate lakes: relevance for subtropical and tropical lakes Restoration and management of tropical eutrophic lakes. In: Reddy, M.V. (Ed.) Restoration and Management of Tropical Eutrophic Lakes, v. 1. CRC Press, Boca Ratón, p.341-359.

Keppeler, E.C. 2003. Abundance of zooplankton from different zones (pelagic and littoral) and time periods (morning and night) in two Amazonian meandering lakes. Acta Scientiarum 25: 287-297.

Kvam, O.V.; Kleiven, O.T. 1995. Diel horizontal migration and swarm formation in Daphnia in response to Chaoborus. Hydrobiologia, 307: 177-184.

Lakens, D. 2013. Calculating and reporting effect sizes to facilitate cumulative science: A practical primer for t-tests and anovas. Frontiers in Psychology, 4: 863-875.

Lass, S.; Spaak, P. 2003. Chemically induced anti-predator defenses in plankton: a review. Hydrobiologia, 491: 221-239.

Leibold, M.A.; Chase, J.M.; Shurin, J.B.; Downing, A.L. 1997. Species turnover and the regulation of trophic structure. Annual Review of Ecology and Systematics, 28: 467- 494.

Leroux, S.J.; Loreau, M. 2008. Subsidy hypothesis and strength of trophic cascades across ecosystems. Ecology Letters, 11: 1147-1156.

Loose, C.J.; von Elert, E.; Dawidowicz, P. 1993. Chemically-induced diel vertical migration in Daphnia - a new bioassay for kairomones exuded by fish. Archiv für Hydrobiologie, 126: 329-337.

Lopes, P.M.; Caliman, A.; Carneiro, L.S.; Bini, L.M.; Esteves, F.A.; Farjalla, V.; Bozelli, R.L. 2011. Concordance among assemblages of upland Amazonian lakes and the structuring role of spatial and environmental factors. Ecological Indicators, 11: 1171-1176.
Matsuzaki, S.S.; Sasaki, T.; Akasaka, M. 2013. Consequences of the introduction of exotic and translocated species and future extirpations on the functional diversity of freshwater fish assemblages. Global Ecology and Biogeography, 22: 1071-1082.

McDowall, R.M. 2006. Crying wolf, crying foul, or crying shame: alien salmonids and a biodiversity crisis in the southern cool-temperate galaxioid fishes? Reviews in Fish Biology and Fisheries, 16: 233-422.

McIntosh, A.R.; Townsend, C.R. 1994. Interpopulation variation in mayfly antipredator tactics: differential effects of contrasting predatory fish. Ecology, 75: 2078- 2090.

McIntyre, P.B.; Flecker, A.S.; Vanni, M.J.; Hood, J.M.; Taylor, B.W.; Thomas, S.A. 2008. Fish distributions and nutrient cycling in streams: can fish create biogeochemical hotspots? Ecology, 89: 2335-2346.

Moss, B.; Stephen, D.; Balayla, D.M.; Bécares, E.; Collings, S.E.; Fernández-Aláez, C. et al. 2004. Continental-scale patterns of nutrient and fish effects on shallow lakes: synthesis of a panEuropean mesocosm experiment. Freshwater Biology, 49: 16331649.

Nackley, L.L.; West, A.G.; Skowno, A.L.; Bond, W.J. 2017. The nebulous ecology of native invasions. Trends in Ecology and Evolution, 32: 814-824.

Nakano, S.; Murakami, M. 2001. Reciprocal subsidies: Dynamic interdependence between terrestrial and aquatic food webs. Proceedings of the National Academy of Sciences of the United States of America, 98: 166-70.

Oksanen, J.; Blanchet, F.G.; Kindt, R.; Legendre, P.; Minchin, P.R.; O'Hara, R.B.; et al. 2015. vegan: Community ecology package R package version 23-0. (http://CRANR-projectorg/package=vegan).

Paiva, S.R.; Dergam, J.A.; Machado, F. 2006. Determining management units in southeastern Brazil: The case of Astyanax bimaculatus (Linnaeus, 1758) (Teleostei: Ostariophysi: Characidae). Hydrobiologia 560: 393-404.

Paolucci, E.M.; MacIsaac, H.J.; Ricciardi, A. 2013. Origin matters: alien consumers inflict greater damage on prey populations than do native consumers. Diversity and Distributions, 19: 988-995.

Polis, G.A.; Holt, R.D. 1992. Intraguild predation: the dynamics of complex trophic interactions. Trends in Ecology and Evolution, 7: 151-155.

Pujoni, D.G.F.; Maia-Barbosa, P.M.; Barbosa, F.A.R.; Fragoso Jr, C.R.; Van Nes, E.H. 2016. Effects of food web complexity on top-down control in tropical lakes. Ecological Modelling, 320: 358-365.

Rahel, F.J. 2000. Homogenization of fish faunas across the United States. Science, 288: 854-856.

Ricciardi, A.; MacIsaac, H.J. 2011. Impacts of biological invasions on freshwater ecosystems. In: Richardson, D.M. (Ed.). Fifty years of invasion ecology: the legacy of Charles Elton, 1st ed, Blackwell Publishing Ltd, Hoboken, p.211-224.

Sala, O.E.; Chapin, F.S.; Armesto, J.J.; Berlow, E.; Bloomfield, J.; Dirzo, R.; et al. 2000. Global Biodiversity Scenarios for the Year 2100. Science, 287: 1770-1774.

Salazar Torres, G.L.; Silva, H.S.; Rangel, L.M.; Attayde, J.L.; Huszar, V.L.M. 2015. Cyanobacteria are controlled by omnivorous filter-feeding fish (Nile tilapia) in a tropical eutrophic reservoir. Hydrobiologia 765: 115-129. 
Santangelo, J.M.; Esteves, F.A.; Tollrian, R.; Bozelli, R.L. 2011. A small-bodied cladoceran (Moina micrura) reacts more strongly to vertebrate than invertebrate predators: a transgenerational life-table approach. Journal of Plankton Research, 33: 1767-1772.

Schindler, D.E.; Scheuerell, M. 2002. Habit coupling in lake ecosystems. Oikos, 98: 117-189.

Shurin, J.B. 2001. Interactive effects of predation and dispersal on zooplankton communities. Ecology, 82: 3404-3416.

Silva, M.F.F.; Menezes, N.L.; Cavalcante, P.B.; Joly, C. 1986. Estudos botânicos: histórico, atualidade e perspectivas. In: Carajás: Desafio Politico, Ecologia e Desenvolvimento. Editora Brasiliense, São Paulo, p.184-207.

Silva, M.S.D.A.; Guimarães, J.T.F.; Filho, P.W.M.S.; Júnior, O.S.; Rodrigues, T.M.; Costa, M.F.D.A. 2018. Morphology and morphometry of upland lakes over lateritic crust, Serra dos Carajás, southeastern Amazon region. Annals of the Brazilian Academy of Sciences, 90: 1-17.

Small, G.E.; Pringle, C.M.; Pyron, M.; Duff, J.H. 2011. Role of the fish Astyanax aeneus (Characidae) as a keystone nutrient recycler in low-nutrient Neotropical streams. Ecology, 92: 386-397.

Solorzano, L. 1969. Determination of ammonia in natural waters by the phenol hypochlorite method. Limnology and Oceanography, 14: 799-801.

Strayer, D.L. 2010. Alien species in fresh waters: ecological effects, interactions with other stressors, and prospects for the future. Freshwater Biology, 55: 152-174.

Strayer, D.L.; Dudgeon, D. 2010. Freshwater biodiversity conservation: recent progress and future challenges. Journal of the North American Benthological Society, 29: 344-358.

Suzumura, M. 2008. Persulfate chemical wet oxidation method for the determination of particulate phosphorus in comparison with a high-temperature dry combustion method. Liminology and Oceanography Methods, 6: 619-629.

van Leeuwen, E.; Lacerot, G.; Van Nes, E.H.; Hemerik, L.; Scheffer, M. 2007. Reduced top-down control of phytoplankton in warmer climates can be explained by continuous fish reproduction. Ecological Modelling, 206: 205-212.

Vadeboncoeur, Y.; McCann, K.S.; Vander Zanden, M.J.; Rasmussen, J.B. 2005. Effects of multi-chain omnivory on the strength of trophic control in lakes. Ecosystems, 8(6):682-693.
Vander Zanden, M.J.; Vadeboncoeur, Y. 2002. Fishes as integrators of benthic and pelagic food webs in lakes. Ecology, 83: 2152-2161.

Vander Zanden, M.J.; Vadeboncoeur, Y.; Chandra, S. 2011. Fish reliance on littoral-benthic resources and the distribution of primary production in Lakes. Ecosystems, 14: 894-903.

Vanni, M.J. 2002. Nutrient cycling by animals in freshwater ecosystems. Annual Review of Ecology and Systematics, 33: 341-370.

Vanni, M.J.; Findlay, D.L. 1990. Trophic cascades and phytoplankton community structure. Ecology, 71: 921-937.

Vanni, M.J.; Flecker, A.S.; Hood, J.M.; Headworth, J.L. 2002. Stoichiometry of nutrient recycling by vertebrates in a tropical stream: linking species identity and ecosystem processes. Ecology Letters, 5: 285-293.

Walls, M.; Kortenailen, I.; Sarvala, J. 1990. Prey responses to fish predation in freshwater communities. Annales Zoologici Fennici, 27: 183-199.

Walsh, J.R.; Carpenter, S.R.; Vander Zanden, M.J. 2016. Invasive species triggers a massive loss of ecosystem services through a trophic cascade. Proceedings of the National Academy of Sciences, 113: 4081-4085.

Williamson, T.J.; Renwick, W.H.; Vanni, M.J.; Bremigan, M.T.; Conroy, J.D. 2018. The importance of nutrient supply by fish excretion and watershed streams to a eutrophic lake varies with temporal scale over 19 years. Biogeochemistry, 6: 233-253.

Winemiller, K.O. 1990. Spatial and temporal variation in tropical fish trophic network. Ecological Monographs, 60: 331-367.

Huot, Y.; Babin, M.; Bruyant, F.; Grob, C.; Twardowski, M.S.; Claustre, H. 2007. Does chlorophyll a provide the best index of phytoplankton biomass for primary productivity studies? Biogeosciences Discussions, 4: 707-745.

Zaret, T.M.; Paine, R.T. 1973. Species introduction in a tropical lake. Science, 182: 449-455.

RECEIVED: $25 / 10 / 2018$

ACCEPTED: $17 / 05 / 2019$

ASSOCIATE EDITOR: Bruno Spacek Godoy 
SUPPLEMENTARY MATERIAL (only available in the electronic version)

NOBRE et al. Effects of the introduction of an omnivorous fish on the biodiversity and functioning of an upland Amazonian lake

Table S1. Abundance of macroinvertebrate species in Violão lake (where the characid Astyanax bimaculatus was introduced) and Amendoim lake (fishless) in Carajás National Forest, Pará state, Brazil in each sampling year and season.

\begin{tabular}{|c|c|c|c|c|c|c|c|c|c|c|c|c|}
\hline \multirow{3}{*}{ ID } & \multirow{3}{*}{ Taxon } & \multicolumn{5}{|c|}{ Violão Lake } & \multicolumn{6}{|c|}{ Amendoim Lake } \\
\hline & & $2010-2011$ & \multicolumn{2}{|c|}{$2011-2012$} & \multicolumn{2}{|c|}{$2012-2013$} & \multicolumn{2}{|c|}{$2010-2011$} & \multicolumn{2}{|c|}{$2011-2012$} & \multicolumn{2}{|c|}{$2012-2013$} \\
\hline & & Dry Rainy & Dry & Rainy & Dry & Rainy & Dry & Rainy & Dry & Rainy & Dry & Rainy \\
\hline & EPHEMEROPTERA & & & & & & & & & & & \\
\hline 1 & Callibaetis sp. & & & & & & & 1 & & & 6 & 2 \\
\hline \multirow[t]{2}{*}{2} & Cloeodessp. & & & & & 2 & & 31 & 7 & & 83 & \\
\hline & ODONATA & & & & & & & & & & & \\
\hline 3 & Acanthagrion sp. 1 & & & 2 & & & & & 20 & 2 & 24 & 1 \\
\hline 4 & Coenagrionidae 1 & & & & & & & 37 & & & & \\
\hline 5 & Erythrodiplax sp. 1 & & & & & 3 & & & & & 6 & 3 \\
\hline 6 & Idiataphesp. & & & & & & & & & 1 & 3 & \\
\hline 7 & Ischnura sp. & & & & & & & & & & & 3 \\
\hline 8 & Lestes bipupillatus Calvert, 1909 & & & & & & & & 1 & 2 & & \\
\hline 9 & Lestes sp. 1 & & & & & & & & & & 5 & 1 \\
\hline 10 & Lestidae & & & & & & & 10 & & & & \\
\hline 11 & Micrathyria sp. 1 & & & & & & & & & 1 & & 2 \\
\hline 12 & Telebasis sp. 2 & & & & & & & & & & & 9 \\
\hline \multirow[t]{2}{*}{13} & Trameasp. & & & 1 & & & & & & & 8 & 2 \\
\hline & HEMIPTERA & & & & & & & & & & & \\
\hline 14 & Ambrysus sp. & & & & & & 10 & 2 & 1 & 2 & & 6 \\
\hline 15 & Ambrysus ståli La Rivers, 1962 & & & & & & & & & & 11 & \\
\hline 16 & Belostoma sp. 1 & & & & & & & 1 & & 5 & 1 & 7 \\
\hline 17 & Buenoa fuscipennis & & & & & & 34 & 5 & & & & \\
\hline 18 & Buenoa platycnemis (Fieber, 1851) & & & & & & 2 & 2 & 1 & & & 1 \\
\hline 19 & Martarega sp. & & & & & & & & 47 & & & \\
\hline 20 & Martarega sp. nov. 1 & & & & & & & & & & & \\
\hline 21 & Martarega uruguayensis & & & & & & & 119 & & 4 & & \\
\hline 22 & Notonecta disturbata Hungerford, 1926 & & & & & & & & & & 5 & \\
\hline 23 & Ranatra sp. 1 & & & & & & & & 1 & 1 & & 4 \\
\hline 24 & Tenagobia sp. 1 & & & & & & & 2 & 4 & & & \\
\hline \multirow[t]{2}{*}{25} & Tenagobia sp. 2 & & & & & & & 1 & & & 42 & \\
\hline & TRICHOPTERA & & & & & & & & & & & \\
\hline \multirow[t]{2}{*}{26} & Oecetis sp. & & & & & & & 2 & & 14 & 2 & 3 \\
\hline & COLEOPTERA & & & & & & & & & & & \\
\hline 27 & Claudiella sp. & & 7 & & & & & & & & & \\
\hline 28 & Coleoptera & & & & & & & & & & & 4 \\
\hline \multirow[t]{2}{*}{29} & Laccophilus sp. 1 & & & & & & & & & & & 3 \\
\hline & DIPTERA & & & & & & & & & & & \\
\hline 30 & Culexsp. & & & & & & & & & & 3 & \\
\hline 31 & Culicidae pupa & & & & & & & & & & 85 & \\
\hline \multirow[t]{2}{*}{32} & Culicinae 1 & & & & & & & & & & 132 & \\
\hline & CHELICERATA & & & & & & & & & & & \\
\hline 33 & Acari & & & & & 18 & & & & & 1 & \\
\hline
\end{tabular}


Table S2. Abundance of zooplankton species in Violão lake (where the characid Astyanax bimaculatus was introduced) and Amendoim lake (fishless) in Carajás National Forest, Pará state, Brazil in each sampling year and season.

\begin{tabular}{|c|c|c|c|c|c|c|c|c|c|c|c|c|c|}
\hline \multirow{3}{*}{ ID } & \multirow{3}{*}{ Taxon } & \multicolumn{6}{|c|}{ Violão Lake } & \multicolumn{6}{|c|}{ Amendoim Lake } \\
\hline & & \multicolumn{2}{|c|}{$2010-2011$} & \multicolumn{2}{|c|}{$2011-2012$} & \multicolumn{2}{|c|}{$2012-2013$} & \multicolumn{2}{|c|}{$2010-2011$} & \multicolumn{2}{|c|}{ 2011-2012 } & \multicolumn{2}{|c|}{$2012-2013$} \\
\hline & & Dry & Rainy & Dry & Rainy & Dry & Rainy & Dry & Rainy & Dry & Rainy & Dry & Rainy \\
\hline & BACILLARIOPHYCEAE & & & & & & & & & & & & \\
\hline 1 & Eunotla sp.10 & & & & & & 67 & & & & & & \\
\hline \multirow[t]{2}{*}{2} & Navicula sp.6 & & & & & & & 187 & & & & & \\
\hline & CHLOROPHYCEAE & & & & & & & & & & & & \\
\hline 3 & Botryococcus sp.1 & & & & & & & 31 & 42 & & & & \\
\hline 4 & Chlorella vulgaris & 233 & 171 & & & & & 78 & 149 & & & & \\
\hline 5 & Desmodesmus maximus & & & & & & 60 & & & & & & \\
\hline 6 & Dictyosphaerium ehrenbergianum & & 16 & & & & & & & & & & \\
\hline 7 & Eutetramorus planctonicus & & 62 & & & & & & & & & & \\
\hline 8 & Koliella longiseta f. variabilis & & 482 & & & & & & 212 & & & & \\
\hline 9 & Monoraphiidum griffithi & & 1012 & & & & & & & & & & \\
\hline 10 & Monoraphidium minutum & 44 & & & & & & 16 & & & & & \\
\hline \multirow[t]{2}{*}{11} & Sphaerocystis sp.1 & & & & & 12 & & & & & & & \\
\hline & CYANOPHYCEAE & & & & & & & & & & & & \\
\hline 12 & Aphanocapsa elachista & 73 & & & & & & 47 & & & & & \\
\hline 13 & Aphanocapsa planctonica & 160 & & & & & & 62 & & & & & \\
\hline 14 & Aphanotece smithii & & & & & & & 109 & & & & & \\
\hline 15 & Geitlerinema amphibium & 233 & & & & & & & & & & & \\
\hline 16 & Lyngbya putealis & & & & & 26 & & & & & & & \\
\hline 17 & Phormidium puteale & & & & & & & & & & & 30 & \\
\hline 18 & Planktolyngbya cf. crassa & & & 45 & & & & & & & & & \\
\hline 19 & Synechococcus nidulans & 190 & & & & & & 31 & & & & & \\
\hline 20 & Synechococcus sp.1 & & & & & & & & 828 & & & & \\
\hline 21 & Synechocystis aquatilis & & & 5089 & 79132 & 3501 & 7888 & & & & & & 10390 \\
\hline 22 & Synechocystis sp.1 & 3283 & 5058 & & & & & 7921 & 5241 & & & & \\
\hline \multirow[t]{2}{*}{23} & Synechocystis sp.2 & & & & & & & & & 5907 & 113912 & & \\
\hline & DINOOPHYCEAE & & & & & & & & & & & & \\
\hline 24 & Dinophyceae 3 & & & & & & & & 631 & & & & \\
\hline 25 & Dinophyceae 8 & & 140 & & & & & 202 & 64 & & & & \\
\hline 26 & Dinophyceae 11 & 379 & & & & & & & & & & & \\
\hline 27 & Gymnodinium sp.2 & 336 & & & & & & & & & & & \\
\hline 28 & Gymnodinium sp.3 & & & & & & & 78 & & & & & \\
\hline 29 & Peridinium africanum & & & & & & & & & 364 & & 229 & \\
\hline 30 & Peridinium sp.3 & & & 182 & & & & & & & & & \\
\hline 31 & Peridinium sp.4 & & 78 & & & & & & & & & & \\
\hline 32 & Peridinium sp.7 & 15 & & & & & & & & & & & \\
\hline & EUGLENOPHYCEAE & & & & & & & & & & & & \\
\hline 33 & Trachelomonas volvocinopsis & 117 & 109 & & & & & 124 & 149 & & & & \\
\hline & ULOTHRICOPHYCEAE & & & & & & & & & & & & \\
\hline 34 & Ulothrix tenerrima & & & & & & 20 & & & & & & \\
\hline & ZYGNEMAPHYCEAE & & & & & & & & & & & & \\
\hline 35 & Actinotaenium wollei & & & & & 35 & & & & & & 58 & \\
\hline 36 & Closterium cynthia & & & & 700 & & & & & & & & \\
\hline 37 & Cosmarium contractum & 233 & & & & & & & & & & & \\
\hline 38 & Cosmarium depressum & & & 1772 & & & & & & & & & \\
\hline 39 & Cosmarium punctulatum & & & & & 40 & & & & & 2801 & & 1050 \\
\hline 40 & Cosmarium sp. 12 & & 296 & & & & & & 2822 & & & & \\
\hline 41 & Desmidiaceae 3 & & & & & & 206 & & & & & & \\
\hline 42 & Desmidium sp.2 & & & & & 784 & & & & & & 230 & \\
\hline 43 & Staurastrum branchiatum & 277 & & & & & & & & & & & \\
\hline 44 & Staurodesmus incus & 88 & & 136 & 2801 & & & & & & & & \\
\hline 45 & Staurodesmus sp.4 & & & & & 1902 & & & & & & & \\
\hline 46 & Staurodesmus spencerianus & & 467 & & & & & & & & 182 & & \\
\hline 47 & Staurodesmus spinarianus & & & 45 & & & & & & & & & \\
\hline 48 & Xanthidium sp.1 & 88 & & & & & & & & & & & \\
\hline
\end{tabular}


Table S3. Abundance of phytoplankton species in Violão lake (where the characid Astyanax bimaculatus was introduced) and Amendoim lake (fishless) in Carajás National Forest, Pará state, Brazil in each sampling year and season.

\begin{tabular}{|c|c|c|c|c|c|c|c|c|c|c|c|c|c|}
\hline \multirow{3}{*}{ ID } & \multirow{3}{*}{ Taxon } & \multicolumn{6}{|c|}{ Violão } & \multicolumn{6}{|c|}{ Amendoim } \\
\hline & & \multicolumn{2}{|c|}{$2010-2011$} & \multicolumn{2}{|c|}{$2011-2012$} & \multicolumn{2}{|c|}{$2012-2013$} & \multicolumn{2}{|c|}{ 2010-2011 } & \multicolumn{2}{|c|}{ 2011-2012 } & \multicolumn{2}{|c|}{$2012-2013$} \\
\hline & & Dry & Rainy & Dry & Rainy & Dry & Rainy & Dry & Rainy & Dry & Rainy & Dry & Rainy \\
\hline & ROTIFERA & & & & & & & & & & & & \\
\hline & Brachionidae & & & & & & & & & & & & \\
\hline \multirow[t]{2}{*}{1} & Anuraeopsis cf. navicula Rousselet, 1910 & 52437 & 1537 & 9288 & & & & 39340 & 8035 & 20927 & 3325 & 151 & 2 \\
\hline & Bdelloidea & & & & & & & & & & & & \\
\hline 2 & Bdelloidea sp.1 & & & & & & & & & & & & 8 \\
\hline \multirow[t]{2}{*}{3} & Bdelloidea sp.8 & & & & & & 4 & & & & & & \\
\hline & Dicranophoridae & & & & & & & & & & & & \\
\hline \multirow[t]{2}{*}{4} & Dicranophorus sp. & & 25 & & & 25 & & & & & & & \\
\hline & Gastropodidae & & & & & & & & & & & & \\
\hline 5 & Ascomorpha agilis Zacharias, 1893 & 4767 & 149 & & & & & 2590 & 654 & & & & \\
\hline \multirow[t]{2}{*}{6} & Gastropus sp. 2 & & & 2288 & & & & & & 2380 & 9810 & & \\
\hline & Lecaniidae & & & & & & & & & & & & \\
\hline 7 & Lecane cf. eutarsa Harring \& Myers, 1926 & & & & & & & 140 & & & & & \\
\hline 8 & Lecane furcata Murray, 1913 & & & & & & & 70 & & & & & \\
\hline 9 & Lecane hornemanni Ehrenberg, 1834 & & & & & & & 70 & & & & & \\
\hline 10 & Lecane ludwigii Eckstein, 1883 & & & & & & & & & & & 3 & 1 \\
\hline 11 & Lecane quadridentata Ehrenberg, 1832 & & & & & & & & & & & & 2 \\
\hline \multirow[t]{2}{*}{12} & Lecane signifera Jennings, 1896 & 1 & 25 & & & 1 & 1 & 210 & & & & 6 & \\
\hline & Lepadellidae & & & & & & & & & & & & \\
\hline 13 & Lepadella cf. patella Müller, 1786 & & & & & & & 140 & & & & & \\
\hline & Notommatidae & & & & & & & & & & & & \\
\hline 14 & Cephalodella gibba Ehrenberg, 1832 & & & & & & & 70 & & & & & \\
\hline 15 & Monommatasp. & & & & & & & 70 & & & & & \\
\hline & Synchaetidae & & & & & & & & & & & & \\
\hline 16 & Polyarthra dolichoptera Idelson, 1925 & 6583 & 11679 & 1077 & & 280 & 5 & 2660 & 9161 & 3471 & 3392 & 264 & \\
\hline 17 & Synchaetasp. & & & 5384 & & & & & & & & & \\
\hline & Testudinellidae & & & & & & & & & & & & \\
\hline 18 & Testudinela ohlei Koste, 1972 & & & & & & & 560 & & & & & \\
\hline & Trichocercidae & & & & & & & & & & & & \\
\hline 19 & Trichocerca cf. bidens Lucks, 1912 & & & & & & & 70 & & & & & \\
\hline 20 & Trichocerca insignis Herrick, 1885 & & 25 & & 28 & & & 350 & & & & & \\
\hline 21 & Trichocerca pusilla Lauterborn, 1898 & 20884 & 2604 & 6192 & & & 3 & 70 & 183 & 99 & & 151 & 2 \\
\hline 22 & Trichocerca similis Wierzejski, 1893 & 80585 & & 1615 & & & & & & & & 113 & 29 \\
\hline & Trichotriidae & & & & & & & & & & & & \\
\hline 23 & Macrochaetus collinsi Gosse, 1867 & & & & & & & & & & 33 & & \\
\hline & CLADOCERA & & & & & & & & & & & & \\
\hline & Bosminidae & & & & & & & & & & & & \\
\hline 24 & Bosminopsis deitersi Richard, 1895 & 32461 & 22 & 52 & 22 & 2 & 1 & & & & & & \\
\hline & Chydoridae & & & & & & & & & & & & \\
\hline 25 & Alona cf. intermedia Sars, 1862 & & & & & & & & & & & 2 & \\
\hline 26 & Alona ossiani Sinev, 1998 & & & & & 2 & & & & & & & \\
\hline 27 & Chydorus pubescens Sars, 1901 & & & & & & & & & & & 2 & \\
\hline 28 & Ephemeroporus barroisi Richard, 1894 & 1 & 2 & & & & & & & & 1 & & \\
\hline & Sididae & & & & & & & & & & & & \\
\hline 29 & Diaphanosoma birgei Korineck, 1981 & 69 & 38 & 105 & 154 & 306 & 100 & & & & & & 557 \\
\hline 30 & Pseudosida ramosa Daday, 1904 & & & 5 & & & & & & & & & \\
\hline & COPEPODA & & & & & & & & & & & & \\
\hline & Cyclopidae & & & & & & & & & & & & \\
\hline 31 & Mesocyclops longisetus longisetus Thiébaud, 1914 & & & & & & & & & 2 & & & \\
\hline 32 & Microcyclops finitimus Dussart, 1984 & & & 9 & 2234 & & & & & & & & \\
\hline 33 & Tropocyclops nananae Reid, 1991 & 16 & 422 & & & 1732 & 199 & & & & & 2 & \\
\hline
\end{tabular}


Table S4. Abundance as number of individuals of chaoborids in Violão Lake (where the characid Astyanax bimaculatus was introduced) and Amendoim Lake (fishless) in Carajás National Forest, Pará state, Brazil in each sampling year and season.

\begin{tabular}{lccc}
\hline Lake & Year & Season & Chaoborids \\
\hline Amendoim & 2010 & Dry & 105 \\
\hline Amendoim & 2011 & Rainy & 461 \\
\hline Amendoim & 2011 & Dry & 36 \\
\hline Amendoim & 2012 & Rainy & 126 \\
\hline Amendoim & 2012 & Dry & 150 \\
\hline Violão & 2010 & Dry & 76 \\
\hline Violão & 2011 & Rainy & 32 \\
Violão & 2011 & Dry & 18 \\
\hline Violão & 2012 & Rainy & 3 \\
\hline Violão & 2012 & Dry & 27 \\
\hline
\end{tabular}

Table S5. Nutrient ratios, measured as Seston molar C:N:P ratios and fish recycling $\mathrm{N}: \mathrm{P}$ ratios (mean \pm SD and number of replicates) in 2012 in Violão Lake (where the characid Astyanax bimaculatus was introduced) in Carajás National Forest, Pará state, Brazil.

\begin{tabular}{|c|c|c|}
\hline & $\begin{array}{c}\text { Rainy Season } \\
\text { (April) }\end{array}$ & $\begin{array}{l}\text { Dry Season } \\
\text { (November) }\end{array}$ \\
\hline \multicolumn{3}{|l|}{ Seston } \\
\hline$C: P$ & $780.60 \pm 91.23(8)$ & $1366.69 \pm 274.66(8)$ \\
\hline$C: N$ & $9.26 \pm 0.68(8)$ & $10.23 \pm 2.16(8)$ \\
\hline$N: P$ & $84.34 \pm 13.77(8)$ & $133.56 \pm 25.91(8)$ \\
\hline \multicolumn{3}{|l|}{ Fish excretion } \\
\hline$N: P$ & $42.80 \pm 32.10(25)$ & $21.25 \pm 6.67(25)$ \\
\hline Redfield (1958) C:N:P & \multicolumn{2}{|c|}{$106: 16: 01$} \\
\hline Hillebrand \& Sommer (1999) C:N:P & \multicolumn{2}{|c|}{$119: 17: 01$} \\
\hline
\end{tabular}
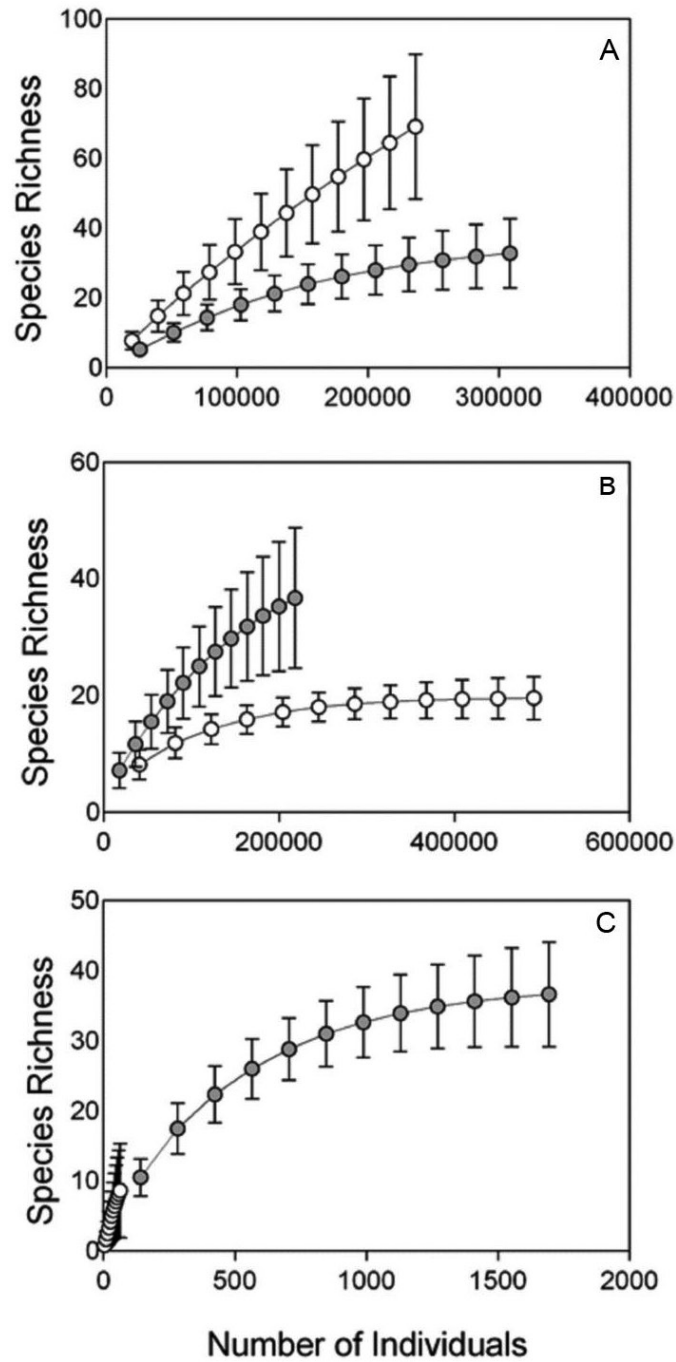

Figure S1. Rarefaction curves, extrapolated by a factor of 2, for species richness comparisons of (a) phytoplankton, (b) zooplankton and (c) littoral macroinvertebrate communities between Amendoim (grey dots) and Violão (white dots) lakes. Bars depict 95\% confidence intervals. 